\title{
THE ROLE OF PRIVATE SECTOR IN DEVELOPMENT PROGRAMME Of SUKAMULYA VILLAGE BAREGBEG SUBDISTRICT CIAMIS
}

\author{
Rira Nuradhawati \\ Universitas Jenderal Achmad Yani \\ rira.nuradhawati@lecture.unjani.ac.id
}

\begin{abstract}
In Sukamulya Village, Baregbeg Subdistrict, Ciamis Regency, at present there are several private sectors that are involved in determining the success of development in the village, the private sector was involved in an effort to accelerate rural development. The research itself was conducted in 2018 in the village of Sukamulya, Baregbeg district, Ciamis Regency. The method used in the study is a qualitative method through literature studies, field observations and very in-depth interviews with Sukamulya villagers. The involvement of private sector at Sukamulya Village make a big change in sukamulya village which had previously been underdeveloped is now a fairly developed village among rural villages in the sub-district. Baregbeg ciamis district, beside that can reduce unemployment there. So from the research we can know that the involvement of Private Sector determines the successful of develompment programme.
\end{abstract}

Keywords—role, private sector, development

\section{INTRODUCTION}

Rural development is an equally important factor in efforts to improve Indonesia's economic growth because the success of rural development is the spearhead of Indonesia's successful development. In journal written by Tifani Ardilah et $\mathrm{al}^{1}{ }^{1}$ it was stated that the successful of village development will impact the successful of national development.The development activities carried out in rural areas provide a lot of influence and impact not only for individuals,

\footnotetext{
${ }^{1}$ Tifani Ardilah, Mochamad Makmur, Imam Hanafi, Jurnal Administrasi Publik (JAP), Vol. 2, No. 1, Hal. 71-77, Upaya Kepala Desa Untuk Meningkatkan Partisipasi Masyarakat Dalam Pembangunan (Studi di Desa Barenng Kecamatan Bareng Kabupaten Jombang), https://media.neliti.com/media/publications/1094-ID-pentingnya-kualitas-aparat-pemerintah-desadalam-pembangunan-di-desa-lantung-kec.pdf
} 
households and communities both in terms of income and also indicators in other quality of life, also influencing the success of a village government in carrying out its policies. Rural development that is felt either directly or indirectly is very significant and real, especially in the creation of employment opportunities as one of the strategies that are quite effective in efforts to alleviate poverty.

The poverty rate in Indonesia, especially in rural areas, can be minimized by efforts to stimulate business in the development of rural local economies and also improve service delivery from the government to the community as well as the private sector as part of the pillar of good governance ${ }^{2}$ in an effort to create a better government.

Private business is part of the sector which is one of the strengths of the Indonesian economic order as a form of embodiment implied in paragraph 2 of Article 33 of the 1945 Constitution and its explanation: Production branches that are important to the state and which affect the livelihood of many people are controlled by the state. The purpose of being controlled by the state according to Mohammad Hatta (1977:28) is, that it does not mean that the state itself is an entrepreneur, entrepreneur or ordernemer. It is more correct to say that state power lies in making regulations for the smooth running of the economy, regulations which also prohibit exploitation of the weak by capital. So the involvement of the private sector requires regulations from the state as the holder of power.

Not all economic activities are carried out by the government, because part of the implementation of economic activities is carried out by the private sector. The business sectors carried out by the private sector are quite diverse, for example in the business of agriculture, industry, trade, tourism and other service businesses. With the wide range of business fields that can be entered by the

\footnotetext{
${ }^{2}$ Kharisma, Bayu, 2014/02/01, Good Governance Sebagai Suatu Konsep dan Mengapa Penting dalam Sektor Publik dan Swasta : Suatu Pendekatan Ekonomi Kelembagaan, Jurnal Buletin Studi Ekonomi Vol.19 No.1. Februari 2014
} 
private sector, it is expected that the private sector can play a large role in efforts to improve development in Indonesia ${ }^{3}$.

The role of the private sector that became the forerunner of change in Sukamulya village is real, not only in economic interests but on the other hand with the involvement of the private sector with the construction of Icakan tourist attractions, widening the road, or opening alinayin road access to Jelat village.

Role is a behavior of someone who is expected to be able to make a change and hope that leads to progress even though not always in accordance with what is expected and as a benchmark for someone as a leader whether that person can improve his performance in carrying out tasks assigned to him so that he will make the person can maximize performance in carrying out his duties. Own role is defined as behavior that is regulated and expected from someone in a certain position (Sarwono, 2015:215).

According to Biddle and Thomas (1966) revealed that role theory is divided into four groups, namely those concerning: 1. People who take part in social interactions; 2. Behavior that appears in the interaction; 3. Position of people in behavior; 4. Linkages between people and behavior.

Some dimensions of the role are as follows: 1 . Role as a policy; 2. Role as a strategy; 3. Role as a communication tool; 4. Role as a dispute resolution tool; 5. Role as a therapy (Horoepoetri, 2003).

The role of the private sector in the economy in Indonesia include

1. Creating employment or employment opportunities

2. Increase the source of state income by paying taxes

3. Participating in the implementation of development

4. Helping in an effort to reduce unemployment

\footnotetext{
${ }^{3}$ Bombong Bintoro Soedjito, 1998, Peran Serta Swasta Dalam Pembangunan Infrastruktur Di Indonesia, Jumal Studi Pembangunan, Vol. I No. 1, Januari 1998. http://perpustakaan.bappenas.go.id/lontar/file?file=digital/98786-[_Konten_]Konten\%2037989.pdf
} 
The research before do by Zainal Asikin. ${ }^{4}$ In this research, identifies several regulations related to public-private partnership (PPP) agreements such as acts, government regulations, presidential regulations, and local byelaws.

The second research by Reny Astuti Manurung. ${ }^{5}$ The purpose of this research is to find out how private and community act in city management, particularly in the small cities of central java with case study in Kupang Kidul, Ambarawa City. The third research come from Andi Yanti Tenri Uji. ${ }^{6}$ The research identifies partnership between the Government and the Private Sector in Kolaka Airport Development Governmental Sangia Nibandera in Kolaka. And then the fourth research by Atika Zahra Rahmayanti . ${ }^{7}$ The research concern about the role of the government and the private sector in the provision of capture fisheries infrastructure with a case study in Bitung. And the fifth research come from Denas Symon ${ }^{8}$ which concern about the role of private sector efforts in public health service

Because in the research before there was no one discussing the role of the private sector in rural development, we felt interested in conducting research that discussed how the role of the private sector in development of the village at Sukamulya Village, Baregbeg Subdistrict, Ciamis Regency. Hope that this research can provide benefits to village officials, the private sector and the village community, how important is the involvement of the private sector in the effort to

\footnotetext{
${ }^{4}$ Zainal Asikin, Vol 25 No 1 2013, Perjanjian Kerjasama Antara Pemerintah dan Swasta Dalam Penyediaan Infrastruktur Publik, https://jurnal.ugm.ac.id/jmh/article/view/16109

${ }^{5}$ Reni Astuty Manurung, Vol 1 No 3, 2013, Peran Masyarakat dan Swasta Dalam Pengelolaan Sampah di Kota Kecil Jawa Tengah (Studi Kasus: Kawasan Kupang Kidul, Ambarawa), Jurnal Wilayah dan Lingkungan.

6 Andi Yanti Tenri Uji , Vol 1 No 2, 2015, Kemitraan Pemerintah Dan Swasta Dalam Pembangunan Bandara Swadaya Sangia Nibandera Kabupaten Kolaka http://journal.unhas.ac.id/index.php/jakpp/article/download/1025/639 Nicole, "Title of paper with only first word capitalized," J. Name Stand. Abbrev., in press.

${ }^{7}$ Atika Zahra Rahmayanti, Vol 7 No 1, 2012, Peran Pemerintah dan Swasta Dalam Penyediaan Infrastruktur Perikanan Tangkap Studi Kasus: Bitung, http://jurnalekonomi.lipi.go.id/index.php/JEP/article/view/225

${ }^{8}$ Denas Symon, Vol 7 No 1 2012, Peranan Sektor Swasta Dalam Upaya Pelayanan Kesehatan Masyarakat, http://jurnal.fkm.unand.ac.id/index.php/jkma/article/view/99
} 
create better development in the village within the framework of good governance.

The data collection technique used in this research covering (1) direct observation (2); interview, and (3) documentation. the data that having been collected is analyzed by using interactive analysis model, data reduction, data presentation and conclusion. To establish and determine the validity of data from research result then, it is required such data testing. In this research the data testing conducted by triangulation technique, those are: checking, re-checking and crosschecking to data obtained from theory, methodology and the researcher perception.

\section{DISCUSSION}

From the result of the research activity, it can be explained the role of private sector in development programme of Sukamulya Village, those are:

\section{A. Role as a policy}

In carrying out its role, the private sector is expected to move in accordance with the policies that have been made with policy makers in this case the village government. From the field we can find out that the village government issued a policy in which the policy gave permission for entrepreneurs especially those who were members of Replica to contribute in carrying out development in Sukamulya village. For example, what was done by Haji Maman by building Icakan tourist attractions which eventually changed functions since 2018 became the center of Islamic religious. It was done by the entrepreneurs with permission from the village government, they helped develop with the widening of the road as a means to support the access of tourists who will visit Icakan tourist attractions. The village of Sukamulya was a backward village, but with the existence and concern of the entrepreneurs who were members of Replica, it was able to change the face of Sukamulya village to become a fairly developed village in the Baregbeg SubDistrict. When the road widening process was carried out, there were raises a polemic between those who agree and not in widening the road but could be resolved peacefully as well as the opening of the 
Alinayin translucent road where the plantations were initially managed by the community. There is little disappointment from the community but all of them can be resolved well without causing conflict in the community. So that, what is done by the entrepreneurs does not deviate from the policies made between the government and the authorities.

\section{B. Role as a strategy}

In carrying out its role in gaining support from the community, there is a considerable amount of appreciation from the community. In an effort to get support, many things were done, for example by the existence of mass circumcision activities, sending umrah with free of charge, giving holiday allowances to honorary teachers (THR). Then work with the government when widening the road by providing compensation that is sufficiently well received by the community whose land is hit when road widening occurs.

At this time the effort to get support from the community is by transferring the function or changing the function of the tourist attractions to become a place for Islamic religion, although on the economic side there are many people who feel the impact by changing the function of the tourist attractions.

By changing the function of Icakan, there are several locations in Icakan can be used by the community to eat with their families without having to pay because it can be used by the general public. At present, in the village of Sukamulya, the Islamic nuances are increasingly felt by changing Icakan's function, because not only people from Sukamulya village came when there were work activities but also from the neighboring villagers came to attend the religious activities.

\section{Role as a communication tool}

The role is utilized as an instrument or tool to get input in the form of information in the decision making process. This perception is based on the idea that the government is designed to serve the community, so that the views and preferences of the community are valuable inputs to realize responsive decisions;

In the role of getting input in the form of information in the decisionmaking process, based on the results of observations in the field, it appears that 
the government in this case the village head and its equipment always involves the community as well as representatives of entrepreneurs when there are development activities or other activities to be carried out in Sukamulya village. The meeting is routinely held every week, known as the minggon meeting, usually held every Thursday at the village office.

So during the meeting there was an exchange of information and also the views of both the government, employers and the community so that a decision could be made that could be accepted by all parties.

Suppose that the actions of these rulers are only armed with permits from the government without involving the elements of society, it is certain that horizontal conflicts will occur in the community. But so far there have been no significant conflicts in the community, indeed there are some people who differ in their views from the policies of employers and also the government but do not become a significant problem. There is always a difference im community and that is a natural thing in a democratic country if there is a difference, and to unite these differences a meeting is held to deliberate to find a solution

\section{Role as a dispute resolution tool}

The role as a dispute resolution tool, the role is utilized as a way to reduce or reduce conflict through efforts to achieve consensus from existing opinions. The assumption underlying this perception is that exchanging ideas and views can increase understanding and tolerance and reduce feelings of distrust and confusion.

In its involvement in development in Sukamulya village, the private sector represented by entrepreneurs who are members of the Replica carry out its role as one of the pillars of good governance by exchanging views or thoughts with the community or with the government so as to reduce or even reduce possible conflicts.

By exchanging ideas or views, it is expected to foster tolerance and reduce distrust and disappointment that may arise as a result of any actions or actions carried out by these entrepreneurs. Because in the field there were found a number 
of parties or groups of people who felt disappointment or dislike of the existence of these entrepreneurs in development activities in Sukamulya village.

But the contra did not develop into a horizontal conflict in the community which would disturb and even endanger the way of life in Sukamulya village. One of the efforts is the existence of religious activities carried out by the private sector, while still involving the existence of the Village Head as the head of the Sukamulya village who is expected to bridge various interests between the government, the community and the private sector. Before it changed its function to become the Islamic Center, when it was still a tourist place, religious activities were also held in mosques in the Icakan tourist area.

In addition to religious activities, interaction between the government, the community and the private sector in the context of exchanging ideas is also through by hobby activities, whether through sports, chess or motocross activities where the Village Head, the private sector and also some community leaders participate in motocross activities.

The exchange of ideas between the three pillars of good governance provides clear evidence that the community, the government and the private sector are determine each other in carrying out development in Sukamulya village, which can be seen in terms of infrastructure, such as roads, village buildings and even village ambulances and also The village's Baitul Maal which has a fairly healthy capital makes Sukamulya village one of the most developed villages in the Baregbeg District. In terms of the accuracy of paying taxes, it deserves appreciation because the people have a high enough awareness to pay the tax.

\section{E. Role as a therapy}

According to this perception, the role is carried out as an attempt at the psychological problems of the community as well as feelings of powerlessness, lack of confidence and the feeling that they are not important components in society.

Furthermore, in an effort to support the existence of the private sector represented by entrepreneurs who are members of Replica, they also carry out their role as therapies specifically seeking solutions from the psychological 
condition of the community who feel that their involvement is not considered and meaningless in development due to limitations in terms of material to support the development in Sukamulya village.

These feelings appeared to arise from several communities when interviewed in the field. They feel that the government prioritizes entrepreneurs by listening more to input from entrepreneurs than input from the community. Of course the feelings that arise from the community must be eliminated through its role as a therapist, by giving motivation to the community when a weekly meeting or religious activity by stating that the existence of the community through their participation greatly determines the success of the development in Sukamulya village.

The community must be given and fostered their self-confidence because with their involvement, especially right to pay taxes in a timely manner, greatly helps their development work when the community pays taxes on time, the funds from the central government will drop on time to help smooth development activities.

Although the funds issued by the private sector are quite large but have no meaning if they are not supported by community participation through material donations as well as labor that is proven when opening the road from Alinayin, the community helps by providing energy by participating in the work to opening the road access.

So that it can be said that the private sector in Sukamulya village is quite good in carrying out its role when involved in the implementation of development in the village of Sukamulya, Subdistrict Baregbeg, Ciamis Regency.

From the discussion above, we know that role theory is a theory used in the world of sociology, psychology as well as anthropology and is a combination of various theories, orientations and disciplines. Role theory discusses the term "role" which is commonly used in the world of theater, where an actor in the theater must play as a certain character and in his position is expected to behave in a certain way. Sarwono $(2015: 215)$ revealed that the position of an actor in the 
theater is analogous to the position of someone in society, and both have similar positions.

Suhardono (1994:4) stated that role actors become aware of the social structure they occupy, therefore an actor tries to always appear "qualified" and is perceived by other actors as "not deviating" from the system of hope that exists in society.

There are five dimensions of the role as follows: 1 . Role as a policy; 2 . Role as a strategy; 3. Role as a communication tool; 4. Role as a dispute resolution tool; 5. Role as therapy.

Role as a policy means that the role is an appropriate and good policy to be implemented; Role as a strategy is a role as a strategy to get support from the community; Role as a communication tool where the role is utilized as an instrument or tool to get input in the form of information in the decision making process. This perception is based on the idea that the government is designed to serve the community, so that the views and preferences of the community are valuable inputs to realize responsive and responsible decisions; Role as a dispute resolution tool, is a role as a way to reduce or reduce conflict through efforts to achieve consensus from existing opinions. The assumption underlying this perception is that exchanging ideas and views can increase understanding and tolerance and reduce feelings of distrust and confusion; Role as therapy is the role taken as an effort to solve the psychological problems of the community as well as feelings of helplessness, lack of confidence and the feeling that they are not important components in society.

In figure 1, it will describe about the role of private sector in development programme at Sukamulya Village, Baregbeg Subdistrict of Ciamis Regency.

Figure 1

\section{The Role Of Private Sector}




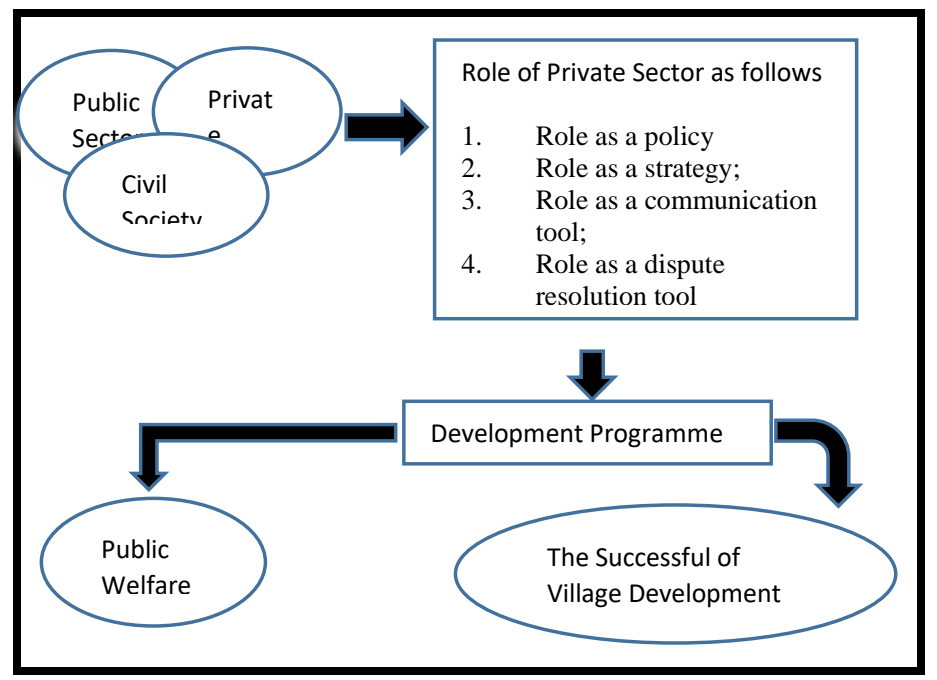

\section{CONCLUSION}

The role of the private sector that became the forerunner of change in Sukamulya village is evident, despite the existence of economic interests but on the other hand with the involvement of the private sector with the construction of Icakan tourist attractions which later function as centers of Islamic activities, road widening, or the opening of alinayin road access in Jelat village made Sukamulya village a fairly advanced village. Investments carried out in villages in local community-based resource infrastructure and also in the form of infrastructure were very significant and provided significant benefits for the economy and also the social conditions of rural communities. In terms of economic indicators there is an increase in income with the opening of wider employment opportunities, productivity and more equitable and better income distribution in the community. Whereas the social benefits felt by the community are a saving of time with easier access to reach the school and also health facilities and the smooth flow of information received by the community.

\section{BIBLIOGRAPHY}


Andi Yanti Tenri Uji, Vol 1 No 2, 2015, Kemitraan Pemerintah Dan Swasta Dalam Pembangunan Bandara Swadaya Sangia Nibandera Kabupaten Kolaka.http://journal.unhas.ac.id/index.php/jakpp/article/download/1025/6 39 Nicole, "Title of paper with only first word capitalized," J. Name Stand. Abbrev., in press.

Atika Zahra Rahmayanti, Vol 7 No 1, 2012, Peran Pemerintah dan Swasta Dalam Penyediaan Infrastruktur Perikanan Tangkap Studi Kasus: Bitung, http://jurnalekonomi.lipi.go.id/index.php/JEP/article/view/225

Biddle, B.J dan Thomas, E.J, 1966. Role Theory : Concept and Research. NewYork : Wiley.

Bombong Bintoro Soedjito, 1998, Peran Serta Swasta Dalam Pembangunan Infrastruktur Di Indonesia, Jumal Studi Pembangunan, Vol. I No. 1, Januari 1998. http://perpustakaan.bappenas.go.id/lontar/file?file=digital/98786[_Konten_]-Konten\%2037989.pdf

Denas Symon, Vol 7 No 1 2012, Peranan Sektor Swasta Dalam Upaya Pelayanan Kesehatan. Masyarakat http://jurnal.fkm.unand.ac.id/index.php/jkma/article/view/99

Edy Suhardono, 1994, Teori Peran (Konsep, Derivasi dan Implikasinya), Jakarta: PT Gramedia Pustaka Utama, Page 4

Horoepoetri, Arimbi, Achmad Santosa, 2003, Peran Serta Masyarakat Dalam Pengelolaan Lingkungan, Jakarta: Walhi..

Kharisma, Bayu, 2014/02/01, Good Governance Sebagai Suatu Konsep dan Mengapa Penting dalam Sektor Publik dan Swasta : Suatu Pendekatan Ekonomi Kelembagaan, Jurnal Buletin Studi Ekonomi Vol.19 No.1. Februari 2014

Mohammad Hatta, 1977, Penjabaran Pasal 33 Undang-Undang Dasar 1945, Jakarta: Mutiara, 1977, page. 28.

Reni Astuty Manurung, Vol 1 No 3, 2013, Peran Masyarakat dan Swasta Dalam Pengelolaan Sampah di Kota Kecil Jawa Tengah (Studi Kasus: Kawasan Kupang Kidul, Ambarawa), Jurnal Wilayah dan Lingkungan.

Sarlito Wirawan Sarwono, 2015, Teori- Teori Psikologi Sosial, Jakarta: Rajawali Pers. Page 215

Tifani Ardilah, Mochamad Makmur, Imam Hanafi, Jurnal Administrasi Publik (JAP), Vol. 2, No. 1, Hal. 71-77, Upaya Kepala Desa Untuk Meningkatkan 
Partisipasi Masyarakat Dalam Pembangunan (Studi di Desa Barenng Kecamatan Bareng Kabupaten Jombang), https://media.neliti.com/media/publications/1094-ID-pentingnya-kualitasaparat-pemerintah-desa-dalam-pembangunan-di-desa-lantung-kec.pdf 